\title{
Natural environments, ancestral diets, and microbial ecology: is there a modern "paleo-deficit disorder"? Part I
}

\author{
Alan C Logan ${ }^{1 *}$, Martin A Katzman² and Vicent Balanzá-Martínez ${ }^{3}$
}

\begin{abstract}
Famed microbiologist René J. Dubos (1901-1982) was an early pioneer in the developmental origins of health and disease (DOHaD) construct. In the 1960s, he conducted groundbreaking experimental research concerning the ways in which early-life experience with nutrition, microbiota, stress, and other environmental variables could influence later-life health outcomes. He also wrote extensively on potential health consequences of a progressive loss of contact with natural environments (now referred to as green or blue space), arguing that Paleolithic experiences have created needs, particularly in the mental realm, that might not be met in the context of rapid global urbanization. He posited that humans would certainly adapt to modern urban landscapes and high technology, but there might be a toll to be paid in the form of higher psychological distress (symptoms of anxiety and depression) and diminished quality of life. In particular, there might be an erosion of humanness, exemplified by declines in altruism/empathy. Here in the first of a two-part review, we examine contemporary research related to natural environments and question to what extent Dubos might have been correct in some of his 50-yearold assertions.
\end{abstract}

\begin{abstract}
"Human beings can almost certainly survive and multiply in the polluted cage of technological civilization, but we may sacrifice much of our humanness in adapting to such conditions... The maintenance of biological and mental health requires that technological societies provide in some form the biological freedom enjoyed by our Paleolithic ancestors".
\end{abstract}

Dr René Dubos, Invited Editorial, Life Magazine, 1970 [1].

\section{Introduction}

Global urbanization is expected to continue with rapid pace over the next several decades, with an additional 1.35 billion people expected to take up residence in cities within the next 15 years [2,3]. Properly planned and managed urbanization, along with the technologically assisted transition from developing to developed areas/

\footnotetext{
* Correspondence: acInd@cfs-fm.org

'CAMNR, 23679 Calabasas Road Suite 542, Calabasas, CA 91302, USA

Full list of author information is available at the end of the article
}

nations, has the potential to promote a host of societal benefits. These include, but are certainly not limited to, undoing poverty, improving sanitation, reducing resource consumption, enhancing efficient commerce and trade, providing educational opportunities, easing of communications, as well as the efficient delivery of government and health-care services. However, translating the promissory notes of urbanicity into realized improvements in future city and metropolitan quality of life is not a simple task $[4,5]$.

The health problems associated with rapid urbanization are profound, most notably the chronic noncommunicable diseases (NCDs)-e.g., mental health disorders, and obesity and its correlates of type II diabetes, metabolic syndrome, and cardiovascular disease [6-13]. Urbanization, particularly in deprived areas, may drive changes in behavior that contribute to NCD risklow physical activity, compromised sleep, and unhealthy dietary choices [14-17]. The progressive movement away from less sanitized traditional lifestyles has also altered the diversity of microbial contact [18]. Much has been 
written regarding environmental variables, including Westernized dietary patterns and increasing microbial sanitization, and their association with marked increases in allergic and autoimmune conditions in developed nations-as much as tenfold higher vs. developing nations [19-21]. The relationship between these variables and mental health is now an emerging area of research $[22,23]$.

Some 4 decades prior to these and other chronic medical conditions being described as "epidemic" and "crisis level," at least one scientist-René J. Dubos (1901-1982) - was providing early warning of impending shifts as they relate to urbanization, loss of biodiversity, and purported technological advances that were in reality (according to Dubos) unrelated to the promotion of human quality of life. Dubos gained his initial fame as a bench microbiologist, the discoverer of the first clinically tested antibiotic (gramicidin, 1939) [24]; over time he would become a noted expert in the field of early environmental influences in long-term health [25] (now referred to as developmental origins of health and disease (DOHaD)) and a Pulitzer-Prizewinning author (So Human an Animal, 1969). A prolific writer, Dubos left a trail of the literature on a wide variety of topics-much of which included a remarkable artistic synthesis of the medical sciences, humanities, and natural and social sciences.

As a highly respected scientist, Dubos understood the value of the most reductionist techniques in the process of scientific discovery; only through detailed and laborintensive examination of isolated mechanisms was he able to uncover the ability of select soil microbes to combat disease-causing bacteria. However, he could also recognize the broad relevance of isolated findings to ecological systems, discussing interrelatedness and connectivity of anthropological and biopsychosocial variables at so many turns. These attributes helped to provide a unique ability in sewing together-both for the scientist and the lay reader-what would seem to be, at least at first glance, distinct and unrelated lines of scientific inquiry. He demonstrated the large-scale saliency of formerly compartmentalized research with an emphasis on personal, societal, and planetary health-all within the context of a rapidly changing, technologically focused world.

Here in this review, the authors will examine, with the benefit of contemporary research findings, to what extent Dubos appears correct in some of his assertions. More specifically, our focus will center on his contention that modern disconnects from ancestral influences-natural environments, traditional dietary practices, and incidental exposure to non-pathogenic microbes-would make itself known in health and well-being statistics (or outcomes related to humanness such as empathy).
Dubos, as evidenced by his own words quoted throughout this review, underscored the importance of these variables. Moreover, from the ecological standpoint of health-both personal and planetary-he expressed that there was essentially no distinction between clearcutting Giant Sequoia forests and doing the same to the non-harmful microbes that reside in the human gut. For Dubos, both practices had untold consequences. He argued that discussions of natural environments, mental health, and the principles of conservation were one in the same.

To be clear at the outset, Dubos was not anti-urban. A city-dweller himself, he wrote often on the many benefits of urban life and its ability to provide a rich milieu for mental growth. He understood that complexities of communities, and the socioeconomic status of those who reside within them, ensure that health does not exist on a neatly defined urban-rural divide. He was a scientist who embraced progress and the highest standards of scientific methodology; however, he was a staunch critic of technological expansion that is simply dressed up as "progress", or more specifically, those developments in which mere convenience or entertainment potential is cloaked under the guise of improving quality of life.

Decades before "paleo" would become a trendy health topic, a niche "lifestyle," or a way of dining that might involve the consumption of relatively expensive food choices [26], Dubos wrote extensively about the health implications of ignoring the indelible Paleolithic inscriptions within the genetic profile of the modern human. Although he wrote on a wide variety of topics, the evolutionary vs. contemporary environmental mismatch was a central theme. The disconnection from nature and ultra-rapid distancing from the environmental influences that shaped us over the millennia, he warned, could easily manifest in chronic disease and compromised mental health.

Dubos argued that because humans are very adaptable, the relationship between an evolutionary mismatch and erosion of health would be stealth-like; there would be only minimal awareness of the association, especially early on in the era of high technology and urbanization. In other words, it would be difficult for the general population and even health-care providers to make connections between current ill health and exceeding adaptive limits in the years or decades prior. Moreover, since humans are also attracted to gadgets and, as Dubos argued, "seem to accept willingly, and indeed to enjoy" many of the biological stresses of mega-city life, it would be even more difficult to appreciate ancestral needs that might be missed in the modern environment [27].

According to Dubos, humans, as a species, would make the necessary adaptations for survival in the technological and increasingly urbanized environment. 
However, survival could not be equated to optimal health or quality of life, and such adaptations may not be without cost to the individual and ultimately to society. The detrimental health effects of the slow and insidious presence of physical and psychological toxins, disturbed circadian rhythms, artificial foodstuffs (all acting in concert with the absence of nature interaction), would bypass identification by most individuals-rather, according to Dubos, they would only be apparent in the overall health statistics of the larger nature-disconnected population over time.

Beyond the specific health effects, he also hypothesized a corrosion of our "humanness," where altruism and empathy would be particularly sensitive to deterioration if ancestral environmental necessities were diluted. In his words:

"Man seems to be adapting to the ugliness of smoky
skies, polluted streams, and anonymous buildings; to
life without the fragrance of flowers, the song of birds,
and other pleasurable stimuli from nature. This
adaptation, however, is only superficial, and
destructive in the long run. Air, water, earth, fire, the
subtle forces of the cosmos, the natural rhythms and
diversity of life have shaped man's nature during the
evolutionary past and have created deep-rooted
sensual and emotional needs that cannot be
eradicated. The impoverishment of sensual and
emotional life will progressively result in the atrophy of
our uniquely human attributes" [28].

\section{Essential background}

Before we examine the unfolding research within our three primary sections-natural environments, traditional diets, and microbiota-it seems critical to discuss the contextual framework in which this research resides. Discussions of natural environments (usually under the green space lexicon), traditional diets, and microbiota are often placed into contemporary research and policy silos. Not only are they separated from one another, but they are rarely placed into larger context of what should be obvious, related discussions.

Changes in screen-based media consumption, with massive increases in the hours devoted to so-called screen time over the last several decades, provide a critical example of contextual framing [29,30]. Indeed, compared to 1960, the per capita time spent devoted to media-based information consumption has increased by $60 \%$ [30]. From an evolutionary perspective, the same dopamine systems that signal ancient rewards-like food and water-also signal for information-seeking. In other words, turning on a smartphone or checking e-mail presents an opportunity to seek rewarding information, and that behavior has the potential to be reinforced [31].
It is not our contention that increases in information consumption are without benefit to human health and well-being. However, given that each day has a fixed 24$\mathrm{h}$ period, the shift toward info-consumption raises obvious questions. As humans spend more time with screen media, are there specific activities or behaviors that have since declined? And, if so, what might be missed from a health perspective? If only through displacement, what might humans no longer be doing, or doing significantly less of, during this 24-h period? Less physical activity, less face-to-face social interactions, and/or less time spent in natural environments?

Screen media consumption is a cultural phenomenon with relevance to each of the main sections of our review-it does not stand alone. Research, admittedly only correlational, indicates that modern technological gadgets and the draw of screen-based media may be contributing to a displacement of nature-based recreation [32-34]. Over the last decade in North America, research indicates that adults and children are spending less time outdoors and significantly more time indoors [35]. The implications are obvious, and we will touch on these in more detail throughout our review-less contact with microbial diversity, changed dietary habits (which, in turn, alter intestinal microbial diversity), and less frequency of the Stone Age nature experiences Dubos considered to be necessary. Could there be a synergy between excess screen media consumption, high cognitive load, and limited time in nature? We will also add the variable of nutrition to this question later. Only through breaking down the silos might we understand if the detrimental health effects may be greater than the sum of these individually researched parts.

Excess screen-based media consumption, information load, and so-called techno-stress have recently been linked with poor psychological health [36-47]. Notwithstanding the potential benefits of media that may specifically foster helping behavior, overall daily screen media use is associated with diminished empathy and the ability to read facial emotions (and other non-verbal cues) that indicate the emotion felt by another $[48,49]$. In 1970, Stanley Milgram published his "urban overload" theory, which posited that the cognitive demands placed on an individual in complex urban environments would diminish the ability to recognize the social cues that might otherwise evoke empathy and altruism [50]. In its wake, a series of experimental studies showed that high levels of cognitive load from environmental inputs were associated with diminished helping behavior-ranging from granting a favor in an office setting, returning an experimental "lost" letter, saving recyclables for a fictitious art project, to helping an individual locate a lost contact lens [51]. 
However, Milgram could not have imagined the extent to which global, mobile communication technologies and internet access would factor into the cognitive load of contemporary environments [52]. The overwhelming amount of consumer choices in contemporary society only adds to the decision-making load [53]. Cognitive load has been shown to reduce the subjective experience of empathy and diminish neural activity in brain regions associated with empathy [54]. Interestingly, investigations involving adults from remote rural regions (living semi-nomadic lifestyles) have shown that, compared to urban residents, they are far less distracted by irrelevant information during cognitive tasks [55].

Evidence does show that urban (vs. rural) upbringing is associated with elevated cortisol responses to acute stress and a blunted cortisol awakening response [56]. Some research shows that attention-deficit hyperactivity levels are higher in urban areas, yet the reasons for an urban-rural gradient remain unclear $[57,58]$. At this point, it is unknown whether provider-diagnosed ADHDwhich has increased threefold in children/teens in the US since 2003 and can vary by as much as 60\% from county-to-county within the same US State $[59,60]$-is a surrogate marker of the pervasive distraction in urban environments.

More relevant to erosion of humanness, emerging research in experimental and real-world settings, shows that the mere presence of mobile communication devices may erode the quality of face-to-face interactions, diminishing closeness, connection, and empathic concern $[61,62]$. Dubos wrote on the topic in 1974:

\begin{abstract}
"Human crowds per se are not responsible for the nervousness of life in modern agglomerations. We suffer less from contact with people than from exposure to the unnatural stimuli generated by the machines that accompany them everywhere in the industrial world. Motor cars, motorcycles, telephones, radios, television sets, and other gadgets enslave us to a nonhuman and often antihuman environment" [63], [page 104].
\end{abstract}

Prospective studies suggest that excess screen time may predict subsequent mental health problems. However, screen time research is complex. For example, research shows that in neighborhoods where walkability is less than optimal, screen time is higher $[64,65]$. Moreover, children residing in urban environments [66] and deprived neighborhoods [67] have higher daily screen time than rural or affluent counterparts. Screen time as it relates to diminished psychological well-being clearly interacts with physical activity, sleep quality, and social support $[68,69]$, yet it may also be an independent variable in the risk of depression [70].
Research also shows that screen time (independently of physical activity) is significantly associated with the consumption of high-energy, low-nutrient foods and beverages [71]. Prospective research shows that baseline screen time predicts higher consumption of sugar-rich beverages when queried 20-24 months later [72,73]. Similar results have been reported concerning baseline screen time and subsequent dietary habits in high school students and young adults-more screen time predicted consumption of fast food, snacks, and high-energy foods and beverages 5 years later [74]. Indeed, total screen time, vs. sedentary time per se, is a better predictor of unhealthy dietary habits among children [75].

Also, crucial to the framing of our review are the massive strides which have been made in the area of evolutionary psychology and the ways in which the findings within the discipline interact with the broad aspects of environmental psychology research [76,77]; the fruits of this labor have made it clear that the brain regulates physiology and behavior via adaptive specializations established via a multi-generational "camping trip" spanning tens of thousands of years [77]. The generalized findings also force us to acknowledge that environmentally influenced aspects of cognition and behavior can occur outside of conscious awareness. Functionally organized systems within the brain were developed out of Stone Age problem-solving necessity, and they still weave their way through the factors with which contemporary mental health clinicians and scientists concern themselves-attention, reasoning, emotion, motivation, and learning [77].

While evolutionary and environmental psychology are expansive domains that have been the subject of recent expert reviews [76,77], in our current context of Dubos, some of the emerging research is worth specific discussion. For example, humans have been shown to rapidly and accurately detect even minor changes in the color or positioning of animals (vs. vehicles, tools, buildings, and other objects) within complex photographic scenes $[78,79]$. Moreover, when subjects are asked to process critical survival-based information in differing experimental contexts (ancestral grassland vs. modern city), there is improved memory in the ancestral setting [80]. Perceptual bias and differential physiological responses for the sights and sounds of ancestral threats (e.g., reptiles or spiders) are detectable even in infants, challenging the idea that social- and experience-based general learning can fully explain common human fears that likely have evolutionary roots $[81,82]$.

The attentional privilege toward animals appears to be a product of a specialized visual recognition system shaped by ancestral selection pressures $[79,83]$. There is also evidence that subsequent to a visit to an urban farmer's market, human spatial memory (the ability to 
recall select locations within $\mathrm{a} \approx 90$ vendor marketplace) is more accurate for locations where foods had a high caloric density. This finding was not related to food preferences or taste-driven desire for those foods, as this had been evaluated prior to the spatial memory exam and subsequently controlled. More likely, the accuracy reflects the ancestral foraging experiences where survival necessitated the securing of nutritionally dense plant foods [84]. Other researchers have found that human preference for the shininess of contemporary glossy (vs. matte) objects appears to be stem from millennia of sourcing a daily supply of fresh, flowing water [85].

While such background research does not necessarily substantiate Dubos's argument that modern urbanites may experience an evolutionary mismatch between certain psychological requirements and the ability of the contemporary environment to help fulfill those needs, it does highlight that the Pleistocene era is still very much (functionally) alive in the brain of the modern human. In addition to the ancestral underpinnings, there are now volumes of research demonstrating the subtle, yet very meaningful, ways in which human cognition and emotion is influenced by environmental variables. The research findings in this area are not simply confined to the effects of noise, lighting, and colors [86-88], they run the gamut from sub-conscious fast-food logo exposure provoking impatience and mitigating the experience of pleasure $[89,90]$, to the ability of subliminal ambient odors (at miniscule levels outside of olfactory awareness) to alter mental performances, preferences, and behavior [91-93]. Again, this background research does not validate the Dubos mismatch theory per se. However, the emerging research does support the broad notion that humans are environmentally influenced in a stealth-like manner, and that as Dubos stated, deterioration in the quality of the physical and social environment "can degenerate without the persons involved being conscious of the loss this entails" [94].

\section{Dubos on privacy}

"Freedom and privacy may come to constitute antisocial luxuries, and even to involve hardships. In consequence, the human beings most likely to prosper in congested urban environments will be those willing to accept a regimented life in a teeming world from which all wilderness and fantasy will have disappeared" [95].

"Just as important for maintaining the quality of human life is an environment in which it is possible to satisfy the longings for quiet, privacy, independence, initiative, and open space. These are not frills or luxuries; they constitute real biological necessities.
They will be in short supply long before there are critical shortages of energy and materials to keep the human machine going and industry expanding" [96].

In order to evaluate some of his claims-that the losses incurred by environmental deterioration, sanitization (loss of contact with biodiversity), technological overwhelm, loss of privacy, and other Paleolithic mismatches would manifest as deficits in the areas of mental health, overall quality of life, and humanness (again, defined by Dubos as altruism and empathy) - we must first determine if the manifestations are actually ongoing. In other words, are there any signs of subtle and not-sosubtle changes in emotional well-being within developed nations and those undergoing the epidemiological transition? The short answer is yes. There seems little doubt that since Dubos wrote one of his final papers, wherein he stated that the most valuable members of future technological societies would be those high in empathy (because those lacking empathy would have little understanding of how to apply rapidly developing "scientific and technological prowess to the deepest concerns of human life" [97]), there have been generational changes in mental health and, especially, in dimensions of personality.

In support of his contention, population studies have shown marked increases in narcissism, anxiety, depression, behavioral disorders, and declines in empathy (in particular, perspective taking and concern for others). The shifts have been most noticeable in the last 2 decades [98-104]. Research in the United States covering the span between 1995 and 2010 shows that outpatient physician visits resulting in mental disorder diagnoses per 100 population have increased significantly (up from 7.78 to 15.30 visits among children and teens and 23.23 to 28.48 visits for adults), and the use of antidepressant medication in the USA has increased by 38\% since 1999 $[105,106]$. Scientists are increasingly taking stock of the mental health consequences of actual and perceived erosions in privacy $[107,108]$.

While a recent meta-analysis indicates that diagnosable depression and anxiety disorders have remained relatively constant since 1990, international studies incorporating the General Health Questionnaire (GHQ) in assessment have, in most cases (8 of 11 studies), reported a significant increase in psychological distress over time (1977-2009 catchment in the same metaanalysis) [109]. Between 1983 and 2009, scores on the Perceived Stress Scale increased by $21 \%$ among American men and women [110]. Researchers are also just beginning to acknowledge the far-reaching and detrimental consequences of so-called sub-threshold mental disorders and steady psychological distress that would otherwise fall short of major diagnosable criteria [111-113]. One third of patients arriving in the offices of primary 
care physicians present with symptoms of depression, anxiety, and/or alcohol problems, yet less than $8 \%$ specifically arrive to address psychiatric symptoms [114].

While researchers and clinicians grapple with diagnostic criteria and terminology related to the definitions of broad terms such as "anxiety" and "depressive symptoms," there seems little doubt that those sitting just outside of the debated criteria, apparently an everincreasing percentage of the global population, are hardly in optimal mental health. The viewpoint of Dubos was along those very sight lines-less focused around an epidemic of mental disorders per se and more concerned with a future erosion of optimal mental health and humanism. Research certainly suggests that his future is now. Dubos argued that separation from the natural world was eroding humanness and that humanness was centrally defined by altruistic and empathic behavior.

"However, the really human aspect of altruism is not its biological origin or its evolutionary advantages but rather the fact that humankind has now made it a virtue regardless of the practical advantages or disadvantages. Since earliest recorded history, altruism has become one of the absolute values by which humanity transcends animality." [115].

To be clear, as much as Dubos mentioned Paleolithic and Stone Age imprints related to modern health, he provided equal time to underscoring the fact that DNA does not determine behavioral destiny. His studies with animals paved the way for behavioral epigenetics. He proved, at least in rodents, that there are adult implications to early-life variables such as maternal grooming, social setting, stress, nutrition, and microbiota contact.

\section{"Through complex mechanisms that are only now being recognized, environmental stimuli determine which parts of the genetic endowment are repressed and which parts are activated. In other words, the life experiences determine the extent to which genetic endowment is converted into functional attributes. From nutrition to education, from topography of the land to religious background, countless are the attributes that contribute to shaping the body and the mind of man" [116], [page 153].}

Some 30 years later, the discovery of epigenetic changes would explain how early-life experiences can indeed be converted into functional attributes [117]. From a pessimistic perspective, the realization that environmental factors can influence neuropsychiatric risk in offspring beyond a single generation (i.e., they can be trans-generational [118,119]) does not bode well in the context of apparent generational increases in psychological distress. On the other hand, the mental health implications of epigenetic processes are cause for optimism because evidence indicates that they are modifiable [120,121].

\section{Natural environments}

\begin{abstract}
"Urban dwellers never have the chance to see the Milky Way, or a night radiant with stars, or even a truly blue sky. They never experience the subtle fragrances peculiar to each season; they lose the exhilaration of early spring and the delightful melancholy of autumn. The loss of these experiences is more than an aesthetic affliction; it corresponds to a deprivation of needs which are essential to physical and mental sanity, because they were indelibly woven in man's fabric during his evolutionary past".
\end{abstract}

René Dubos in Bailey A [122].

Dubos argued that access to and contact with natural environments was essential to the mental health of populations; therefore, an appropriate starting point is to examine in top-down fashion-i.e., through an epidemiological lens-the recent scientific assessments of the relationship between nature and mental well-being. A variety of population-level studies have provided support to the notion that natural environments are associated with health promotion in urban settings. Studies have linked the perceived degree of greenness of urban neighborhoods with individual life satisfaction and mental health among residents $[123,124]$.

Researchers using a land-use database in the Netherlands have also discovered associations between higher levels of neighborhood green space, and both self-reported general health and a decreased risk of physician-assessed diseases. Specific to mental health, those with $\leq 10 \%$ green space within $1 \mathrm{~km}$ of the residence had a $25 \%$ greater risk of depression and a $30 \%$ greater risk of anxiety disorders vs. residents with the highest concentration of green space in proximity to the home $[125,126]$. A separate investigation from Denmark reported that residing more than $1 \mathrm{~km}$ from high green space areas was associated with a $42 \%$ increase in high levels of self-reported stress and poor scores on measurements of general health, vitality, overall mental health, and bodily pain [127].

In a USA study that included rural and urban communities, researchers compared mental health outcomes with an objectively determined vegetation index and percentage of neighborhood tree canopy coverage. It was reported that residence in areas with a high ratio of green space was associated with better mental health. Lower risk of depression was, in particular, strongly linked to neighborhood green space with each 
measurement-vegetation index, tree canopy, and an average of the two [128]. In a study involving urban New Zealand residents, every $1 \%$ increase in the proportion of useable or total green space in proximity to the home was associated with a $4 \%$ lower rate of anxiety/mood disorder treatment [129]. If Dubos were alive today, he would perhaps be unsurprised that decreasing the residential distance to the nearest usable green space seemed to diminish the need for clinical interventions in anxiety and depression.

Supporting this overall connection between urban green space and mental health, researchers using the British Household Panel Survey (BHPS) found that residential relocation to or from areas with more/less green space was associated with mental health. Specifically, the researchers found that (vs. premove data and controlling for income) the 594 individuals who moved to areas higher in green space had better mental health scores on each of the subsequent years. These sustained mental health improvements, observed through 3 years of study, were not realized in the years following a move to a less green area [130]. The BHPS and a land-use data set have also shown that better mental and general health is associated with residence in proximity to coastal regionsso-called blue space-an association that was observed to be independent of green space [131].

Studies involving community samples have also examined green space in relation to objective markers of stress physiology. For example, lower residential greenness is associated with higher blood pressure among 10 year-old children living in an urban Munich, Germany [132]. Studies involving socially disadvantaged urban adults in Scotland have found that salivary cortisol follows a healthy pattern in association with lower perceived stress in those residing in areas containing higher ( $>43 \%$ green space) $[133,134]$. Although better access to natural environments does seem to encourage the cardio-protective activity of recreational walking, research indicates that physical activity does not always mediate the relationship between green environments and health outcomes [135], indicating that there may be as-yet-undetermined mechanisms that explain the benefits of green space for human health.

\section{Epidemiology-contextual findings}

Although our focus is on mental health, there are a number of additional population studies that can be considered relevant to the Dubos' argument concerning the need for natural environments. Depressive and anxiety disorders have been found to be drivers of chronic disease states-most notably type II diabetes, cardiovascular, and gastrointestinal diseases and disorders [136-141]. Therefore, if green space is associated with mental well-being, as indicated by the research cited above, it would certainly suggest that it might also be associated with reduced mortality rates.

Indeed, a variety of international studies have linked regional forests [142], regional green space [143], walkable green space [144], urban parks [145], and overall urban green space with lowered mortality rates [146,147]. The latter study controlled for socio-economic status and found that the combination of low income and low residential-area green space was associated with cardiovascular mortality rates twice that of those living in more affluent areas. However, when low income was paired with high levels of residential-area urban green space, mortality rates for disadvantaged communities vs. affluent areas narrowed significantly [147].

Separate research on the beneficial effects of green space concentration and pregnancy outcomes (birth weight and preterm risk) and the higher risk of postpartum depression in urban vs. rural environments [148-152] indicates the far-reaching effects of natural environments. Considering that children born preterm (vs. peers delivered full term) are at significantly higher risk of mental disorders [153], a generational influence of natural environments could be possible. Also, in a sample of almost 260,000 Australians, higher percentage green space in neighborhoods $(80 \%$ or more vs. $20 \%$ or less) was associated with a diminished likelihood of short sleep duration [154]. Given the links between normal sleep duration, psychological well-being, and decreased risk of obesity $[155,156]$, these findings are of relevance to public health.

The results of the cited Australian study [154] are particularly intriguing because the link between green space and healthy sleep duration was not associated with physical activity, socioeconomic status, or current psychological distress. The daily use of natural environments might facilitate the benefits of natural light delivered to the retina at the right time of day [157]. The extent to which areas containing as much as $80 \%$ green space (as reported in [154]) is associated with less outdoor light at night (LAN), which in turn might influence sleep $[158,159]$ and mental health [160], needs to be explored.

Urbanization has been linked with reduced infant sleep [161] and experimental research demonstrates long-term consequences of dim light at night in early life, on subsequent anxiety and other neuropsychiatric disorders [162]. In adults, sleep debt is known to compromise emotional empathy [163]. The degree of artificial skyglow (i.e., light pollution via scattering of light in the atmosphere) in dense urban areas can easily match and exceed than that of the brightest summer moonlight, and its ability to obscure visibility of stars and potentially place significant pressure on ecological systems is not a matter of debate [164,165]. Moreover, massive 
increases in man-made electromagnetic radiation to accommodate technological devices [166,167], especially in densely populated areas, may also influence the circadian systems and sleep quality $[168,169]$.

\section{Dubos on light}

"Until the last century, man lived in the dark for long hours...modern man, in contrast, is exposed to bright light for 16 hours a day. In view of the fact that light rays can affect several hormonal activities, and that many, if not most, physiological functions are linked to circadian and seasonal cycles, it seems possible that this change in the ways of life will have long-range consequences for the human species" [170].

\section{Dubos on radiation}

"Throughout his life and evolution, man has been exposed to a background of radiation from natural sources. This normal background, which seems to have remained fairly constant, at least in geologically recent times, must therefore be a tolerable factor of human environment... and it is unlikely that adaptive processes can occur fast enough to cope with the potential long-range dangers if man-made radiation continues to increase at its present rate" [171].

If natural environments are working toward the promotion of public health, mental health in particular, we would expect there to be consequences when such environments are subjected to degradation. Unrelenting industrial activities, climate change, invasive species-or a combination of the lot-are examples of environmental variables that can visibly alter natural environments, sometimes in a relatively short period of time. Although the research in this area remains limited, there is evidence that environmental degradation, including changes to vegetation and tree loss at the community and regional level, is associated with increased physical illness and declining mental health, including depression and a loss of sense of place [172-177]. When researchers used three-dimensional videos to evaluated the extent to which differing urban tree density might mitigate stress induction in volunteers, the benefits were noted in a linear fashion-greater density of urban street tree canopy was associated with more effective self-reported stress recovery. As the researchers point out, it appears that every tree matters [178].

The epidemiological research related to natural environments does have some shortcomings, not the least of which includes a common reliance upon cross-sectional design and the use of self-reports. However, the population research does not stand alone. It is bolstered by a variety of in vivo and experimental studies which point in the direction of Dubos-i.e., an evolutionary need for natural environments, one that stands apart independently of other variables, the awareness of which could be masked in the midst of shifting priorities.

In his words concerning the future of the human masking of that need-"In fact, he may soon forget that some of his most exhilarating experiences have come from direct contact with freshness, brilliance, and rich variety of unspoiled natural phenomenon. Unfortunately, perhaps, starless skies and joyless sceneries are not incompatible with the maintenance of life, or even with physical health. The only measure of their loss may be a progressive decadence in the quality and sanity of the human condition" [179].

\section{Natural environments-in vivo research}

Increasingly, researchers are engaging in studies that compare activities (most often walking) in natural environments vs. the same activity conducted in the built environment. In an effort to advance the quality of the research, investigators are beginning to employ pre/postobjective measurements of physiology and utilize validated instruments of neuropsychological relevance. For example, researchers induce neurocognitive fatigue with mentally challenging tasks designed to place demands on sustained attention. Immediately following this intense cognitive effort, the subjects take a walk (varying times, typically 30-60 $\mathrm{min}$ ) in a vegetation-rich park or on city streets and at the conclusion of the walk, neuropsychological tests are repeated. Using this general design, researchers have reported more significant cognitive benefits post-nature walk in healthy adults $[180,181]$, children with deficits in attention [182], and adults with depression [183].

Some of the research indicates that this so-called cognitive restoration was occurring without changes in emotional state per se, suggesting that the cognitive benefits are not merely the result of acute positive mental outlook [183]. Separate research, involving 56 adults engaged in a wilderness hiking excursion, found that 4 days into the hike the scores on the Random Associates Test (used for creative thinking and insight problem solving) were 50\% higher vs. pre-hike scores [184]. Research involving 51 university students has also showed that when subjects are randomly queried (via pager at various times between 10a and 10p) about current activities and vitality, even when the presence of others, physical activity and outdoor environments in general were controlled for, the presence of natural elements was a mediator of subjective vitality [185].

Added to the weight of such studies is a large volume of research under the umbrella term of shinrin-yoku (translates from Japanese as "forest bathing" or "taking 
in the forest") and related descriptive of forest therapy. Reviews and original research on the subject through 2010 captured nine studies involving field work evaluating forest walking or comfortably seated viewing/ contemplation of the forest (vs. urban built) environment. These studies have reported, perhaps unsurprisingly, that the forest experience improved subjective mood state. However, the mood changes have been corroborated with physiological findings-e.g., lower cortisol levels, reduced sympathetic tone, improved natural killer cell count/activity, lowered pulse rate and blood pressure, and improved heart rate variability $[186,187]$. Since the publication of these reviews, additional studies, including those from China and Korea, have documented similar improvements in subjective mood and end points such as stress hormones, oxidative stress, systemic inflammation, and blood pressure [188-196].

\section{Natural environments-objective markers}

The argument that natural environments may be a deeply rooted means to buffer contemporary stress is strengthened by the results of objective neurophysiology and imaging studies. For example, electroencephalograph (EEG) has reported higher alpha wave activity, suggesting a state of relaxed wakefulness and lowered anxiety, when viewing scenes of natural environments [197-199]. Changes in real-time EEG measurements during a 25-min walk (participants walked from an urban shopping district through a vegetation-rich urban park) were associated with emotional parameters indicating less frustration, higher engagement, and a more meditative state while transitioning through green space [200]. Japanese researchers have used near-infrared timeresolved spectroscopy (NITRS) to measure oxygen use in the brain via the reflection of near-infrared light from red blood cells. In separate reports, they have shown that viewing an outdoor forest setting (vs. urban control), actual plant foliage (vs. projected images), and a three-dimensional plant image (vs. two-dimensional), changed cerebral oxygen use in ways that might substantiate subjective reports of mental focus and/or relaxation [201-203].

Several functional magnetic resonance imaging (fMRI) studies have demonstrated divergent brain activation patterns during the presentation of urban built vs. natural environment scenery [204-207]. With relative consistency in these studies, scenes of natural environments increased activity in regions associated with positive affect, emotional stability, altruism, empathy, and depth of love. The urban scenes, in contrast, increased activity in the amygdala, an area well-documented to be a hub in arousal, risk, and threat detection. Interestingly, it has been reported that urban adults (or those who grew up in an urban vs. rural environment) have increased activity in the amygdala while performing challenging tasks and researcher-induced perceived social stress [208].

Separate fMRI work has revealed that images of blue sky with some green vegetation can activate the same areas of the brain that are provoked by positive (vs. neutral or negative) images. In addition, the sky images activated unique areas associated with expanse of space, circadian rhythms, and dreaming [209]. The extent to which environmental colors (e.g., blue and green) mediate brain activation in areas associated with emotional response is an active area of investigation [210].

Researchers have also used scenes of natural environments to determine if they may influence markers of stress physiology. For example, in the immediate period following a laboratory stressor, markers of stress physiology (electromyography, skin conductance, and/or pulse transit time show a more rapid return to baseline after viewing scenes of nature vs. urban environments deficient in vegetation [211]. Spending time in nature, activities associated with gardening, or simply viewing scenes of nature, has been associated with favorable responses as measured by autonomic control and heart rate variability [212-216]. For example, viewing scenes of nature vs. an urban built environment for $10 \mathrm{~min}$ prior to a mental stressor results in enhanced heart rate variability and more dominant parasympathetic activity [216]. These studies are not confined to the visual system alone; there is also research indicating similar physiological and mood effects using auditory (sounds of nature), olfactory (volatile chemicals released from leaves), and even tactile (touch of real leaf vs. synthetic leaf made of resin) stimuli [217-222].

\section{Natural environments-cognition, altruism, and discounting}

Several studies have found inverse relationships between childhood play experiences in green/blue spaces and hyperactivity and/or inattention [223-226]. One of those studies also found that beach attendance among children aged 7-11 is associated with pro-social behavior [227]. A growing body of research also suggests that natural environments may be an effective means to mitigate some of the consequences of the cognitive load characteristic of modern urban environments [228,229].

The results of laboratory experiments certainly validate the notion that viewing scenes of nature (vs. urban built scenes) can lead to more rapid recovery of cognitive performance (executive attention, memory recall, target identification, reaction time, logical reasoning, and anagram task performance) in the period following challenging activities known to induce mental fatigue [230-234]. Using a similar modus operandi of induced cognitive fatigue prior to field-setting walks, researchers 
find performance benefits after walking in nature vs. the urban built environment $[181,183]$. There are also indications that proximity of academic settings in relations to natural environments, and classroom views to natural environments, may be associated with positive academic performance [235-237]. Similar findings concerning benefits of window views to nature (or the presence of indoor potted plants) have been reported where the end point was workplace performance [238-240].

If natural environments can improve positive emotions and limit cognitive fatigue, they may also help with future discounting and the erosion of helping behavior associated with cognitive load. Volumes of research show that humans discount the value of future rewards, instead prioritizing smaller immediate rewards. Greater discounting of the future in favor of a small reward has been associated with impulsivity, depression, obesity, and a host of detrimental lifestyle habits [241-243]. The overall cognitive load within an urban environment, perceived competition for resources, and even physical aspects of the built environment may magnify delay discounting. Indeed, researchers have found that viewing scenes of nature or being in urban natural environments (vs. control scenes of, and actually being in, the urban built environment) is associated with significant reductions in discounting the future. Nature scenes or being in nature minimizes impulsivity and enhances the value assigned to future reward [244,245].

Moving toward altruism, researchers have found that exposure to images of natural environments (vs. built environment) is associated with increased intrinsic aspirations (e.g., depth of meaning within relationships, personal growth, and community value) and devalued extrinsic aspirations (e.g., accumulation of wealth, personal image, status, and fame). Similar results were found when (without participant knowledge) four plants were either present or absent in the laboratory)-higher value was placed on intrinsic aspirations when plants were in the room. The presence of plants was also associated with increased generosity in an economic decision-making task [246].

A series of field experiments demonstrated increased helping behavior (returning a "lost" glove) after random subjects had walked through a natural environment within a town center [247]. The helping behavior appeared to be mediated by positive mood induction via very brief periods (approximately $1 \mathrm{~min}$ ) spent in the natural environment. In addition, the induction of awe by nature scenes has also been shown to direct attention away from the self and toward the environment, increasing feelings of connectivity to others, and enhancing the desire to spend time in nature or take on creative pursuits [248].

Of relevance to the hurried urban existence, where the perception of lack of time encourages unhealthy lifestyle habits, it is noteworthy that the induction of awe by nature scenes has been shown to increase the perception of time availability. In turn, this translates into decreased impatience and increased willingness to volunteer. When awe is induced, there is also a preference for experiential rewards (e.g., an event) vs. rote material goods (e.g., a wristwatch) of equal value [249].

This research certainly supports the humanistic view of Dubos. His assertions that ongoing technological and cultural changes would mask awareness of the potential of health via natural environments-i.e., that it would not be consciously missed-have been indirectly evaluated by noted Canadian researcher Elizabeth Nisbet and colleagues. Although there may be no historical data with which to compare, Nisbet has consistently found that contemporary Westernized adults undervalue the psychological value of nature [250]. For example, she has determined that prior to engaging in 17-min walk in urban green space (vs. indoor environments), adults consistently undervalue the subsequent actualized improvement in positive affect. Importantly, the researchers found that walking in the outdoors facilitated a sense of nature relatedness [251]. Fostering a connection to nature or awareness of its benefits provides an optimistic perspective. Higher scores on validated scales can capture an individual's "nature relatedness", "connectedness with nature", and "nature connectivity"; higher scores are significantly correlated with lower anxiety and anger, a more positive mental outlook, greater well-being, and overall vitality [252-256].

The link between nature connectivity and personal well-being is found in student and community samples of adults with broad-ranging ages, occupations, and health status [252-254]. Researchers are untangling the psychological mediators that appear to strengthen the connections between nature, helping behavior, cognitive function, and personal well-being; they include the degree of awareness/mindfulness, meaning in life, perceptions of beauty, and positive affect [257-261]. We wonder what the epigenetic implications of such mediators might be.

Critically, higher scores on nature relatedness are also associated with pro-environmental attitudes-greater concern for all living things (see Biophilia and Biophilism section below), the broad community and future generations [250,254]. Higher scores on the nature relatedness scales are also positively and significantly associated with empathy [262]. Short-term induction of nature connectivity, should it be consistent over time, may offer a means to improve some aspects of personal health and positive attitudes toward the environment, although these long-term benefits from isolated shortterm nature experiences in urban settings remain speculative [263]. 
It should be pointed out that the benefits of nature interventions on psychological well-being do not seem to be predicated on an individual's baseline nature relatedness, and these benefits, in turn, appear to motivate the individual to maintain nature-based experiences [264]. Therefore, it seems reasonable to conclude that opportunity is a prerequisite to develop a connection to nature. Over time, this may influence attitudes-for example, it is noteworthy that the perceived potential of a natural environment to produce cognitive restoration may be linked to pro-environmental attitudes of the users [265].

\section{Natural environments-benefits of biodiversity}

As we transition our discussions toward other potential evolutionary mismatches (or paleo-deficits) in Part II, we conclude Part I with the topic of biodiversity. Dubos had much to say concerning the loss of biodiversity and forewarned that discussions of biodiversity loss should not be privileged by select species that are emotionally favored by humans. Even the lowly microbe was as relevant as the Giant Sequoia in his biodiversity discussions:

"man himself has emerged from a line descent that began with microbial life, a line common to all plant and animal species... [he] is dependent not only on other human beings and on the physical world but also on other creatures-animals, plants, microbesthat have evolved together with him. Man will ultimately destroy himself if he thoughtlessly eliminates the organisms that constitute essential links in the complex and delicate web of life of which he is a part" [266].

Of course, rapid urbanization is a significant driver of global biodiversity loss [267]. In turn, given the critical role of biodiversity in global health [268-270], the impacts of its loss may also be stealth-like, tallied only through the aggregate of public health statistics. Moreover, the psychological benefits of local biodiversity may also be without conscious realization. For example, research has shown that as it relates to human health and well-being, the benefits of urban green spaces appear to be related to the extent of their overall biodiversity [271-273].

Remarkably, when humans hear birdsongs in the background of an experimental setting in which they are tasked with rating urban environments, their appreciation for scenes of urban landscapes is increased along a gradient coincident with the diversity of audible birdsongs [274]. We have much to learn about the ways in which biodiversity has shaped us. However, it seems apparent that, as Dubos likely would have argued, we cannot make up for these potential losses with a birdsong-generating machine from a high-end gadget outlet.

\section{Other paleo-deficits}

Emerging studies certainly support Dubos in his contention that revisiting certain "Paleolithic experiences," at least the more pleasant ones (vs. those that might have helped develop our efficient fight or flight response), could have a positive influence on metropolitan quality of life. However, the modern urban environment may be missing more than merely green/blue space, natural sounds, and light at the right time. The ability of green spaces to facilitate social contacts is an important consideration [275]. Children who reside in close proximity to urban green spaces and forests are significantly less likely to engage in excessive screen time [276]; therefore, the dialogue on natural environments cannot take place in isolation. As we outline in Part II, there are other interrelated discussions that often escape discourse in the context of natural environments yet may be no less relevant with regard to what is missing in the modern landscape vs. our ancestral past-diversity of microbes and traditional dietary patterns.

\section{Biophilia and biophilism-some history}

It is commonly stated that biophilia (Greek-bios (life), philia (love)) is a 20th century neologism that was "coined" in the 1980s. However, the term biophilia appeared in many 19th century medical and psychology dictionaries as meaning not only love of life but also the instinct for self-preservation common to man and the lower animals [277]. It was Charles J. Adams, a religious scholar and author, who popularized the term biophilism in the late 19th and early 20th century.

In 1895, Adams formed a "Bureau of Biophilism", which included the well-known naturalist John Burroughs, poets Henry Abbey and Eugene Field, dog expert Eugene Glass, et al. [278]. Writing in professional as well as lay periodicals such as Forest and Stream and Dog Fancier $[279,280]$, Adams argued that biophilism was not merely the love of one's own life, it was also the love of nonhuman life, even that of lower animals. "Biophilism means the love of life. The love of what sort of life"? Adams queried in a 1907 article [281], answering his own question by stating that "out of self love one should come into...love of humanity, out of love of humanity into love of all sentient things. When he has so far evolved, he is a biophilist. As there may be born a poet, so there may be born a biophilist". However, Adams argued that although birth can provide the ingredients for biophilism, it could only be realized if the innate powers, as he called them, were "more than drawn out. They must be developed, trained" through experience. 
References to biophilia and biophilism waned until the mid-20th century when psychologist Eric Fromm provided some renewed enthusiasm for the term as it pertains to mental state. Although Fromm made little reference to nature or the environment per se, others did so for him. For example, in 1969 scholar Michael McGrath interpreted Fromm's biophilia [282] in a way that might be captured by contemporary Nature Relatedness Scales-"A simple form of biophilous behavior is that of plants leaning toward the source of sunlight... biophilia confirms and promotes life. The biophilous person produces rather than destroys, creates rather than hoards. He is more interested in living things, such as nature and other people, than he is 'dead' things such as sports cars and spaceships".

Biophilia, as in the love of all life on Earth, was subsequently positioned in the early 1970 s as a potential benefit to environmental conservation [283]. In 1979, biologist Edward O. Wilson argued the following in The New York Times-“Our deepest needs stem from ancient and still poorly understood biological adaptations. Among them is biophilia: the rich, natural pleasure that comes from being surrounded by living organisms, not just other human beings but a diversity of plants and animals that live in gardens and woodlots, in zoos, around the home and in the wilderness" [284]. Dubos, to our knowledge, never used the term biophilia, preferring instead a "biological joie de vivre" that could be obtained through solidarity with other forms of life.

Said Dubos-“...the essential factors of biological joie de vivre exist in every human being because they are inscribed in the genetic code. In fact, this aspect of life has probably not changed significantly since the Stone Age...the purely biological enjoyment of life can, in addition, evolve into a more subtle experience of universal fellowship with all other human beings and even with other forms of life...ever since the Stone Age, and in all parts of the world, human beings have expressed their awareness of solidarity with other forms of life...." [63].

\section{Competing interests}

$\mathrm{ACL}$ has received consulting fees from Genuine Health Inc (Toronto, ON, Canada). He is co-author of the trade paperback Your Brain on Nature (Harper Collins, 2012). MAK and VBM declare that they have no competing interests.

\section{Authors' contributions}

All authors made significant contributions to the manuscript. ACL provided the primary framework for the content. MAK and VBM provided oversight and important intellectual content within each major section. All authors read and approved the final manuscript

\section{Author details}

'CAMNR, 23679 Calabasas Road Suite 542, Calabasas, CA 91302, USA. ²TART Clinic for Mood and Anxiety Disorders, 32 Park Road, Toronto, ON M4W 2 N4, Canada. ${ }^{3}$ Department of Medicine, Section of Psychiatry and
Psychological Medicine, University of Valencia Medical School, Avda. Blasco Ibáñez, 15, E46010 Valencia, Spain.

Received: 19 August 2014 Accepted: 2 January 2015

Published online: 31 January 2015

References

1. Dubos R. Mere survival is not enough for man. Life. 1970;69:2

2. Seto KC, Güneralp B, Hutyra LR. Global forecasts of urban expansion to 2030 and direct impacts on biodiversity and carbon pools. Proc Natl Acad Sci U S A. 2012;109:16083-8.

3. United Nations. World urbanization prospects: the 2011 revision. New York. 2012. http://www.un.org/en/development/desa/publications/worldurbanization-prospects-the-2011-revision.html

4. Jones-Smith JC, Popkin BM. Understanding community context and adult health changes in China: development of an urbanicity scale. Soc Sci Med. 2010;71:1436-46.

5. Dora C, Haines A, Balbus J, Fletcher E, Adair-Rohani H, Alabaster G, et al. Indicators linking health and sustainability in the post-2015 development agenda. Lancet 2014. In press.

6. Penkallas AM, Kohler S. Urbanicity and mental health in Europe: a systematic review. Eur J Mental Health 2014. In press.

7. Ginter E, Simko V. Type 2 diabetes mellitus, pandemic in 21st century. AdvExp Med Biol. 2012;771:42-50

8. Gong P, Liang S, Carlton EJ, Jiang Q, Wu J, Wang L, et al. Urbanisation and health in China. Lancet. 2012;379:843-52.

9. Danaei G, Singh GM, Paciorek CJ, Lin JK, Cowan MJ, Finucane MM, et al. The global cardiovascular risk transition: associations of four metabolic risk factors with national income, urbanization, and Western diet in 1980 and 2008. Circulation. 2013;127:1493-502.

10. Adediran OS, Adebayo PB, Akintunde AA. Anthropometric differences among natives of Abuja living in urban and rural communities: correlations with other cardiovascular risk factors. BMC Res Notes. 2013;6:123.

11. Wagner $\mathrm{KH}$, Brath $\mathrm{H}$. A global view on the development of non communicable diseases. Prev Med. 2012;54(Suppl):S38-41.

12. Delisle H, Ntandou-Bouzitou G, Agueh V, Sodjinou R, Fayomi B. Urbanisation, nutrition transition and cardiometabolic risk: the Benin study. Br J Nutr. 2012;107:1534-44

13. McKenzie K, Murray A, Booth T. Do urban environments increase the risk of anxiety, depression and psychosis? An epidemiological study. J Affect Disord. 2013;150:1019-24.

14. Cyril S, Oldroyd JC, Renzaho A. Urbanisation, urbanicity, and health: a systematic review of the reliability and validity of urbanicity scales. BMC Public Health. 2013;13:513.

15. Ng SW, Howard AG, Wang HJ, Su C, Zhang B. The physical activity transition among adults in China: 1991-2011. Obes Rev. 2014;15 Suppl 1:27-36.

16. Bedrosian TA, Nelson RJ. Influence of the modern light environment on mood. Mol Psychiatr. 2013;18:751-7.

17. Riha J, Karabarinde A, Ssenyomo G, Allender S, Asiki G, Kamali A, et al. Urbanicity and lifestyle risk factors for cardiometabolic diseases in rural Uganda: a cross-sectional study. PLoS Med. 2014;11:e1001683.

18. Rutkowski K, Sowa P, Rutkowska-Talipska J, Sulkowski S, Rutkowski R. Allergic diseases: the price of civilisational progress. Postepy Dermatol Alergol. 2014;31:77-83.

19. Bendiks M, Kopp MV. The relationship between advances in understanding the microbiome and the maturing hygiene hypothesis. Curr Allergy Asthma Rep. 2013;13:487-94.

20. Kondrashova A, Seiskari T, llonen J, Knip M, Hyöty H. The 'hygiene hypothesis' and the sharp gradient in the incidence of autoimmune and allergic diseases between Russian Karelia and Finland. APMIS. 2013;121:478-93.

21. Manzel A, Muller DN, Hafler DA, Erdman SE, Linker RA, Kleinewietfeld M. Role of "Western diet" in inflammatory autoimmune diseases. Curr Allergy Asthma Rep. 2014;14:404.

22. Logan $A C$, Jacka FJ. Nutritional psychiatry research: an emerging discipline and its intersection with global urbanization, environmental challenges, and the evolutionary mismatch. J Physiol Anthropol 2014. In press.

23. Selhub EM, Logan AC, Bested AC. Fermented foods, microbiota, and mental health: ancient practice meets nutritional psychiatry. J Physiol Anthropol. 2014;33:2.

24. Van Epps HL. René Dubos: unearthing antibiotics. J Exp Med. 2006;203:259. 
25. Dubos R. Lasting biological effects of early influences. Perspect Biol Med. 1969;12:479-91.

26. Metzgar M, Rideout TC, Fontes-Villalba M, Kuipers RS. The feasibility of a Paleolithic diet for low-income consumers. Nutr Res. 2011;31:444-51.

27. Dubos R. Environmental biology. Biosci. 1964;14:11-4.

28. Dubos R. Man overadapting. Psychology Today. 1971;4(Feb):5-53.

29. Strasburger VC, Hogan MJ. Children, adolescents, and the media. Pediatrics. 2013;132:958-61

30. Bohn R, Short J. Measuring consumer information. Int J Comm. 2012;6:980-1000.

31. Bromberg-Martin ES, Hikosaka O. Midbrain dopamine neurons signal preference for advance information about upcoming rewards. Neuron. 2009:63:119-26.

32. Pergams $\mathrm{O}$, Zaradic $\mathrm{P}$. Evidence for a fundamental and pervasive shift away from nature-based recreation. Proc Natl Acad Sci U S A. 2008;105:2295-300.

33. Pergams $\mathrm{O}$, Zaradic $\mathrm{P}$. Is love of nature in the US becoming love of electronic media? 16-year downtrend in national park visits explained by watching movies, playing video games, internet use, and oil prices. J Environ Manage. 2006;80:387-93.

34. Siikamaki J. Contributions of the US state park system to nature recreation. Proc Natl Acad Sci U S A. 2011;108:14031-6.

35. Matz CJ, Stieb DM, Davis K, Egyed M, Rose A, Chou B, et al. Effects of age, season, gender and urban-rural status on time activity. Int J Environ Res Publ Health. 2014;11:2108-24.

36. Twenge JM. Does online social media lead to social connection or social disconnection? J Coll Char. 2013:14:11-20.

37. Chen W, Lee KH. Sharing, liking, commenting, and distressed? The pathway between Facebook interaction and psychological distress. Cyberpsychol Behav Soc Netw. 2013;16:728-34.

38. Kross E, Verduyn P, Demiralp E, Park J, Lee DS, Lin N, et al. Facebook use predicts declines in subjective well-being in young adults. PLoS One. 2013;8:e69841

39. Becker MW, Alzahabi R, Hopwood CJ. Media multitasking is associated with symptoms of depression and social anxiety. Cyberpsychol Behav Soc Netw. 2013;16:132-5.

40. Primack B, Swanier B, Georgiopoulos AM, Land SR, Fine MJ. Association between media use in adolescence and depression in young adulthood. Arch Gen Psychiatr. 2009;66:181-8.

41. Van den Eijnden R, Meerkerk GJ, Vermulst AA, Spijkerman R, Engels RC. Online communication, compulsive internet use, and psychological well-being among adolescents: a longitudinal study. Dev Psychol. 2008;44:655-65.

42. Salanova M, Llorens S, Cifre E. The dark side of technologies: technostress among users of information and communication technologies. Int J Psychol. 2013;48:422-36.

43. Lucas M, Mekary R, Pan A, Mirzaei F, O'Reilly EJ, Willett WC, et al. Relation between clinical depression risk and physical activity and time spent watching television in older women: a 10-year prospective follow-up study. Am J Epidemiol. 2011:174:1017-27.

44. Misra S, Stokols D. Psychological and health outcomes of perceived information overload. Environ Behav. 2012:44:737-59.

45. Kominiarczuk N, Ledzinska N. Turn down the noise: information overload, contentiousness, and their connection to individual wellbeing. Pers Indiv Diff. 2014;60(Suppl):S76.

46. Lepp A, Barkley JE, Karpinski AC. The relationship between cell phone use, academic performance, anxiety, and satisfaction with life in college students. Comput Hum Behav. 2014;31:343-50.

47. Zheng F, Gao P, He M, Li M, Wang C, Zeng Q, et al. Association between mobile phone use and inattention in 7102 Chinese adolescents: a population-based cross-sectional study. BMC Publ Health. 2014;14:1022.

48. Uhls YT, Michikyan M, Morris J, Garcia D, Small GW, Zgourou Z, et al. Five days at outdoor education camp without screens improves preteen skills with nonverbal emotion cues. Comp Hum Behav. 2014;39:387-92.

49. Prot S, Gentile DA, Anderson CA, Suzuki K, Swing E, Lim KM, et al. Long-term relations among prosocial-media use, empathy, and prosocia behavior. Psychol Sci. 2014;25:358-68.

50. Milgram S. The experience of living in cities. Science. 1970;167:1461-8.

51. Cohen S. Environmental load and attention allocation. In: Baum A, editor. Advances in environmental psychology, the urban environment, vol, vol. 1. Hillsdale, NJ: Halsted Press; 1978. p. 1-29.

52. Stokols D, Misra S, Runnerstrom MG, Hipp JA. Psychology in an age of ecological crisis: from personal angst to collective action. Am Psychol. 2009;64:181-93.
53. Peters E, Klein W, Kaufman A, Meilleur L, Dixon A. More is not always better: intuitions about effective public policy can lead to unintended consequences. Soc Issues Policy Rev. 2013;7:114-48.

54. Morelli SA, Lieberman MD. The role of automaticity and attention in neural processes underlying empathy for happiness, sadness, and anxiety. Front Neurosci. 2013;7:1-15.

55. Linnell KJ, Caparos S, Davidoff J. Urbanization increases left-bias in linebisection: an expression of elevated levels of intrinsic alertness? Front Psychol 2014. In press.

56. add Steinheuser $V$, Ackermann $K$, Schönfeld $P$, Schwabe L. Stress and the city. Impact of urban upbringing on the (re)activity of the hypothalamuspituitary-adrenal axis. Psychosom Med 2014. In press.

57. Siddique S, Banerjee M, Ray MR, Lahiri T. Attention-deficit hyperactivity disorder in children chronically exposed to high level of vehicular pollution. Eur J Pediatr. 2011;170:923-9.

58. Baumgardner DJ, Schreiber AL, Havlena JA, Bridgewater FD, Steber DL, Lemke MA. Geographic analysis of diagnosis of attention-deficit/ hyperactivity disorder in children: Eastern Wisconsin. USA Int J Psychiatr Med. 2010:40:363-82.

59. Visser SN, Danielson ML, Bitsko RH, Holbrook JR, Kogan MD, Ghandour RM, et al. Trends in the parent-report of health care provider-diagnosed and medicated attention-deficit/hyperactivity disorder: United States, 2003-2011. J Am Acad Child Adolesc Psychiatr. 2014;53:34-46. e2.

60. Frey JJ. Understanding the 'what' before the 'why' in population research. WMJ. 2013:112:9-10

61. Przybylski AK, Weinstein N. Can you connect with me now? How the presence of mobile communication technology influences face-to-face conversation quality. J Soc Pers Relat. 2013;30:237-46.

62. Misra S, Cheng L, Genevie J, Yuan M. The iPhone effect: the quality of in-person social interactions in the presence of mobile devices. Environ Behav 2014. In press

63. Dubos R. Beast or angel? New York: Charles Scribner's Sons; 1968.

64. Ding D, Sugiyama T, Winkler E, Cerin E, Wijndaele $K$, Owen N. Correlates of change in adults' television viewing time: a four-year follow-up study. Med Sci Sports Exerc. 2012;44:1287-92.

65. Sugiyama T, Salmon J, Dunstan DW, Bauman AE, Owen N. Neighborhood walkability and TV viewing time among Australian adults. Am J Prev Med. 2007:33:444-9

66. Salmon J, Veitch J, Abbott G, ChinAPaw M, Brug JJ, teVelde SJ, et al. Are associations between the perceived home and neighbourhood environment and children's physical activity and sedentary behaviour moderated by urban/rural location? Health Place. 2013;24:44-53.

67. Tandon PS, Zhou C, Sallis JF, Cain KL, Frank LD, Saelens BE. Home environment relationships with children's physical activity, sedentary time, and screen time by socioeconomic status. Int J Behav Nutr Phys Act. 2012;9:88.

68. Costigan SA, Barnett L, Plotnikoff RC, Lubans DR. The health indicators associated with screen-based sedentary behavior among adolescent girls: a systematic review. J Adolesc Health. 2013;2:382-92.

69. Cao H, Qian Q, Weng T, Yuan C, Sun Y, Wang H, et al. Screen time, physical activity and mental health among urban adolescents in China. Prev Med. 2011;53:316-20.

70. Feng Q, Zhang QL, Du Y, Ye YL, He QQ. Associations of physical activity, screen time with depression, anxiety and sleep quality among Chinese college freshmen. PLoS One. 2014;9:e100914.

71. Al-Hazzaa HM, Al-Sobayel HI, Abahussain NA, Qahwaji DM, Alahmadi MA, Musaiger AO. Association of dietary habits with levels of physical activity and screen time among adolescents living in Saudi Arabia. J Hum Nutr Diet. 2014;27 Suppl 2:204-13.

72. Olafsdottir S, Berg C, Eiben G, Lanfer A, Reisch L, Ahrens W, et al. Young children's screen activities, sweet drink consumption and anthropometry: results from a prospective European study. Eur J Clin Nutr. 2014:68:223-8.

73. Gebremariam MK, Bergh IH, Andersen LF, Ommundsen Y, Totland TH, Bjelland $\mathrm{M}$, et al. Are screen-based sedentary behaviors longitudinally associated with dietary behaviors and leisure-time physical activity in the transition into adolescence? Int J Behav Nutr Phys Act. 2013;10:9.

74. Barr-Anderson DJ, Larson NI, Nelson MC, Neumark-Sztainer D, Story M. Does television viewing predict dietary intake five years later in high school students and young adults? Int J Behav Nutr Phys Act. 2009;6:7.

75. Borghese MM, Tremblay MS, Leduc G, Boyer C, Bélanger P, LeBlanc AG, et al. Independent and combined associations of total sedentary time and 
television viewing time with food intake patterns of 9- to 11-year-old Canadian children. Appl Physiol Nutr Metab. 2014;14:1-7.

76. Gifford R. Environmental psychology matters. Annu Rev Psychol. 2014;65:541-79.

77. Cosmides L, Tooby J. Evolutionary psychology: new perspectives on cognition and motivation. Annu Rev Psychol. 2013;64:201-29.

78. Wang S, Tsuchiya N, New J, Hurlemann R, Adolphs R. Preferential attention to animals and people is independent of the amygdala. Soc Cogn Affect Neurosci 2014. In press

79. New J, Cosmides L, Tooby J. Category-specific attention for animals reflects ancestral priorities, not expertise. Proc Natl Acad Sci U S A. 2007;104:16598-603.

80. Nairne JS, Pandeirada JN. Adaptive memory: ancestral priorities and the mnemonic value of survival processing. Cogn Psychol. 2010;61:1-22.

81. LoBue V, DeLoache JS. Superior detection of threat-relevant stimuli in infancy. Dev Sci. 2010;13:221-8.

82. Erlich N, Lipp OV, Slaughter V. Of hissing snakes and angry voices: human infants are differentially responsive to evolutionary fear-relevant sounds. Dev Sci. 2013;16:894-904

83. Van Le Q, Isbell LA, Matsumoto J, Nguyen M, Hori E, Maior RS, et al. Pulvinar neurons reveal neurobiological evidence of past selection for rapid detection. Proc Natl Acad Sci U S A. 2013;110:19000-5.

84. New J, Krasnow MM, Truxaw D, Gaulin SJ. Spatial adaptations for plant foraging: women excel and calories count. Proc Biol Sci. 2007;274:2679-84.

85. Meert K, Pandelacre M, Patrick VM. Taking a shine to it: how the preference for glossy items stems from an innate need for water. J Consum Psychol. 2014;24:195-206.

86. Klatte M, Bergström K, Lachmann T. Does noise affect learning? A short review on noise effects on cognitive performance in children. Front Psychol. 2013:4:578.

87. Knez I. Affective and cognitive reactions to subliminal flicker from fluorescent lighting. Conscious Cogn. 2014;26:97-104

88. Elliot AJ, Maier MA. Color psychology: effects of perceiving color on psychological functioning in humans. Annu Rev Psychol. 2014;65:95-120.

89. DeVoe SE, House J, Zhong CB. Fast food and financial impatience: a socioecological approach. J Pers Soc Psychol. 2013;105:476-94.

90. House J, DeVoe SE, Zhong CB. Too impatient to smell the roses: exposure to fast food impedes happiness. Soc Psychol Pers Sci. 2014;5:534-41.

91. Li W, Moallem I, Paller KA, Gottfried JA. Subliminal smells can guide social preferences. Psychol Sci. 2007;18:1044-9.

92. Gaillet-Torrent M, Sulmont-Rossé C, Issanchou S, Chabanet C, Chambaron S. Impact of a non-attentively perceived odour on subsequent food choices. Appetite. 2014;76:17-22.

93. Yamada Y, Sasaki K, Kunieda S, Wada Y. Scents boost preference for novel fruits. Appetite. 2014;81C:102-7

94. Parma V, Tirindelli R, Bisazza A, Massaccesi S, Castiello U. Subliminally perceived odours modulate female intrasexual competition: an eye movement study. PLoS One. 2012;7:e30645.

95. Dubos R. So human an animal. New York: Charles Scribner's Sons; 1968.

96. Dubos R. Does man have a future? Center Reports. 1971:4:60.

97. Dubos R. Education for the celebration of life: optimism despite it all. Teachers Coll Rec. 2013;84:266-76.

98. Twenge JM. Overwhelming evidence for generation me. Emerg Adulthood. 2013;1:21-6.

99. Twenge JM, Kasser T. Generational changes in materialism and work centrality, 1976-2007: associations with temporal changes in societal insecurity and materialistic role modeling. Pers Soc Psychol Bull. 2013;39:883-97.

100. Twenge JM, Campbell WK, Freeman EC. Generational differences in young adults' life goals, concern for others, and civic orientation, 1966-2009. Pers Soc Psychol. 2012;102:1045-62.

101. Twenge J, Miller JD, Campbell WK. The narcissism epidemic: commentary on modernity and narcissistic personality disorder. Pers Disord. 2014;5:227-9.

102. Matijasevich A, Murray E, Stein A, Anselmi L, Menezes AM, Santos IS, et al. Increase in child behavior problems among urban Brazilian 4-year olds: 1993 and 2004 Pelotas birth cohorts. J Child Psychol Psychiatry 2014. In press.

103. Perou R, Bitsko RH, Blumberg SJ, Pastor P, Ghandour RM, Gfroerer JC, et al. Mental health surveillance among children-United States, 2005-2011. MMWR Surveill Summ. 2013;62 Suppl 2:1-35.

104. Neumann M, Edelhäuser F, Tauschel D, Fischer MR, Wirtz M, Woopen C, et al. Empathy decline and its reasons: a systematic review of studies with medical students and residents. Acad Med. 2011;86:996-1009.
105. Olfson M, Blanco C, Wang S, Laje G, Correll CU. National trends in the mental health care of children, adolescents, and adults by office-based physicians. JAMA Psychiatr. 2014;71:81-90.

106. Mojtabai R, Olfson M. National trends in long-term use of antidepressant medications: results from the U.S. National Health and Nutrition Examination Survey. J Clin Psychiatr. 2014;75:169-77.

107. Siegel AW. Inequality, privacy, and mental health. Int J Law Psychiatr. 2008;31:150-7.

108. Nouskalis G. Biometrics, e-identity, and the balance between security and privacy: case study of the passenger name record (PNR) system. Sci World J. 2011;11:474-7.

109. Baxter AJ, Scott KM, Ferrari AJ, Norman RE, Vos T, Whiteford HA. Challenging the myth of an "epidemic" of common mental disorders: trends in the global prevalence of anxiety and depression between 1990 and 2010. Depress Anxiety. 2014;31:506-16.

110. Cohen S, Janicki-Deverts D. Who's stressed? Distributions of psychological stress in the United States in probability samples from 1983, 2006, and 2009. J Appl Soc Psychol. 1983;2012(42):1320-34

111. Haller H, Cramer H, Lauche R, Gass F, Dobos GJ. The prevalence and burden of subthreshold generalized anxiety disorder: a systematic review. BMC Psychiatr. 2014;14:128.

112. Pietrzak RH, Maruff $P$, Woodward M, Fredrickson J, Fredrickson A, Krystal JH, et al. Mild worry symptoms predict decline in learning and memory in healthy older adults: a 2-year prospective cohort study. Am J Geriatr Psychiatr. 2012;20:266-75.

113. Rai D, Kosidou K, Lundberg M, Araya R, Lewis G, Magnusson C. Psychological distress and risk of long-term disability: population-based longitudinal study. J Epidemiol Community Health. 2012;66:586-92.

114. Nordström A, Bodlund $O$. Every third patient in primary care suffers from depression, anxiety or alcohol problems. Nord J Psychiatr. 2008;62:250-5.

115. Dubos R. The humanness of the human species. Sci News. 1974;106:346-7.

116. Dubos R. Environmental determinants of human life. In: Glass DC, editor. Environmental Influences. New York: Rockefeller University Press; 1968. p. 138-54.

117. Weaver IC, Szyf M, Meaney MJ. From maternal care to gene expression: DNA methylation and the maternal programming of stress responses. Endocr Res. 2002;28:699.

118. Gillette R, Miller-Crews I, Nilsson EE, Skinner MK, Gore AC, Crews D. Sexually dimorphic effects of ancestral exposure to vinclozolin on stress reactivity in rats. Endocrinology 2014. In Press.

119. Vialou V, Feng J, Robison AJ, Nestler EJ. Epigenetic mechanisms of depression and antidepressant action. Annu Rev Pharmacol Toxicol. 2013:53:59-87.

120. Szyf M. Epigenetics, a key for unlocking complex CNS disorders? Eur Neuropsychopharmacol 2014. In press.

121. Walker AK, Hawkins G, Sominsky L, Hodgson DM. Transgenerational transmission of anxiety induced by neonatal exposure to lipopolysaccharide: implications for male and female germ lines. Psychoneuroendocrinology. 2012;37:1320-35.

122. Bailey A. Rene Dubos: men of ideas. Horizon. 1970;12:56-61

123. Vemuri AW, Grove MJ, Wilson MA, Burch WR. A tale of two scales: evaluating the relationship among life satisfaction, social capital, income, and the natural environment at the individual and neighborhood levels in metropolitan Baltimore. Environ Behav. 2011;43:3-25.

124. Sugiyama T, Leslie E, Giles-Corti B, Owen N. Associations of neighbourhood greenness with physical and mental health: do walking, social coherence and local social interaction explain the relationships? J Epidemiol Community Health. 2008:62:e9.

125. Maas J, Verheij RA, de Vries S, Spreeuwenberg P, Schellevis FG Groenewegen PP. Morbidity is related to a green living environment. J Epidemiol Community Health. 2009;63:967-73.

126. Maas J, Verheij RA, Groenewegen PP, de Vries S, Spreeuwenberg P. Green space, urbanity, and health: how strong is the relation? J Epidemiol Community Health. 2006;60(7):587-92.

127. Stigsdotter UK, Ekholm O, Schipperijn J, Toftager M, Kamper-Jørgensen F, Randrup TB. Health promoting outdoor environments-associations between green space, and health, health-related quality of life and stress based on a Danish national representative survey. Scand J Pub Health. 2010;38:411-7.

128. Beyer K, Kaltenbach A, Szabo A, Bogar S, Nieto FJ, Malecki KM. Exposure to neighborhood green space and mental health. Int J Environ Publ Health Res. 2014;11:3453-72. 
129. Nutsford D, Pearson AL, Kingham S. An ecological study investigating the association between access to urban green space and mental health. Publ Health. 2013;127:1005-11.

130. Alcock I, White MP, Wheeler BW, Fleming LE, Depledge MH. Longitudinal effects on mental health of moving to greener and less green urban areas. Environ SciTechnol. 2014;48:1247-55.

131. White MP, Alcock I, Wheeler BW, Depledge MH. Coastal proximity, health and well-being: results from a longitudinal panel survey. Health Place. 2013;23:97-103.

132. Markevych I, Thiering E, Fuertes E, Sugiri D, Berdel D, Koletzko S, et al. A cross-sectional analysis of the effects of residential greenness on blood pressure in 10-year old children: results from the GINIplus and LISAplus studies. BMC Publ Health. 2014;14:477.

133. Thompson CW, Roe J, Aspinall P, Mitchell R, Clow A, Miller D. More green space is linked to less stress in deprived communities: evidence from salivary cortisol patterns. Landsc Urban Plan. 2012;105:221-9.

134. Roe JJ, Thompson CW, Aspinall PA, Brewer MJ, Duff El, Miller D, et al. Green space and stress: evidence from cortisol measures in deprived urban communities. Int J Environ Res Publ Health. 2013;10:4086-103.

135. Lachowycz K, Jones AP. Does walking explain associations between access to greenspace and lower mortality? Soc Sci Med. 2014;107:9-17.

136. Husarewycz MN, El-Gabalawy R, Logsetty S, Sareen J. The association between number and type of traumatic life experiences and physical conditions in a nationally representative sample. Gen Hosp Psychiatr. 2014;36:26-32.

137. Sullivan MD, Katon WJ, Lovato LC, Miller ME, Murray AM, Horowitz KR, et al. Association of depression with accelerated cognitive decline among patients with type 2 diabetes in the ACCORD-MIND trial. JAMA Psychiatr. 2013;70:1041-7.

138. Ma Y, Balasubramanian R, Pagoto SL, Schneider KL, Hébert JR, Phillips LS, et al. Relations of depressive symptoms and antidepressant use to body mass index and selected biomarkers for diabetes and cardiovascular disease. Am J Publ Health. 2013;103:e34-43.

139. Currier MB, Nemeroff CB. Depression as a Risk Factor for Cancer. From pathophysiological advances to treatment implications. Annu Rev Med 2013. In press.

140. Nemeroff CB, Goldschmidt-Clermont PJ. Heartache and heartbreak-the link between depression and cardiovascular disease. Nat Rev Cardiol. 2012;9:526-39.

141. Masand PS, Keuthen NJ, Gupta S, Virk S, Yu-Siao B, Kaplan D. Prevalence of irritable bowel syndrome in obsessive-compulsive disorder. CNS Spectr. 2006;11:21-5.

142. Li Q, Kobayashi M, Kawada T. Relationships between percentage of forest coverage and standardized mortality ratios (SMR) of cancers in all prefectures in Japan. Open Pub Health J. 2008;1:1-7.

143. Hu Z, Liebens J, Rao KR. Linking stroke mortality with air pollution, income, and greenness in northwest Florida: an ecological geographical study. Int J Health Geogr. 2008;7:20.

144. Takano T, Nakamura K, Watanabe M. Urban residential environments and senior citizens' longevity in megacity areas: the importance of walkable green spaces. J Epidemiol Community Health. 2002;56:913-8.

145. Takano T, Fu J, Nakamura K, Uji K, Fukuda Y, Watanabe M, et al. Age-adjusted mortality and its association to variations in urban conditions in Shanghai. Health Pol. 2002;61:239-53.

146. Villeneuve PJ, Jerrett M, Su JG, Burnett RT, Chen H, Wheeler AJ, et al. A cohort study relating urban green space with mortality in Ontario. Canada Environ Res. 2012;115:51-8.

147. Mitchell R, Popham F. Effect of exposure to natural environment on health inequalities: an observational population study. Lancet. 2008;372:1655-60.

148. Laurent O, Wu J, Li L, Milesi C. Green spaces and pregnancy outcomes in Southern California. Health Place. 2013;24:190-5.

149. Agay-Shay K, Peled A, Crespo AV, Peretz C, Amitai Y, Linn S, et al. Green spaces and adverse pregnancy outcomes. Occup Environ Med. 2014:71:562-9.

150. Vigod SN, Tarasoff LA, Bryja B, Dennis CL, Yudin MH, Ross LE. Relation between place of residence and postpartum depression. CMAJ. 2013;185:1129-35.

151. Dadvand P, Wright J, Martinez D, Basagana X, McEachan R, Cirach M, et al. Inequality, green spaces, and pregnant women: roles of ethnicity and individual and neighborhood socioeconomic status. Environ Int. $2014 ; 71: 101-8$
152. Hystad P, Davies HW, Frank L, Van Loon J, Gehring U, Tamburic L, et al Residential greenness and birth outcomes: evaluating the influence of spatially correlated built-environment factors. Environ Health Perspect. 2014;122:1095-102.

153. Rogers CE, Lenze SN, Luby JL. Late preterm birth, maternal depression, and risk of preschool psychiatric disorders. J Am Acad Child Adolesc Psychiatr. 2013;52:309-18.

154. Astell-Burt T, Feng $X$, Kolt GS. Does access to neighbourhood green space promote a healthy duration of sleep? Novel findings from a cross-sectional study of 259319 Australians. BMJ Open. 2013;3:8.

155. Wong ML, Lau EY, Wan JH, Cheung SF, Hui CH, Mok DS. The interplay between sleep and mood in predicting academic functioning, physical health and psychological health: a longitudinal study. J Psychosom Res. 2013;74:271-7.

156. Ford ES, Li C, Wheaton AG, Chapman DP, Perry GS, Croft JB. Sleep duration and body mass index and waist circumference among US adults. Obesity. 2014:22:598-607.

157. Zadeh RS, Shepley MM, Williams G, Chung SS. The impact of windows and daylight on acute-care nurses' physiological, psychological, and behavioral health. HERD. 2014;7:35-61.

158. Vollmer C, Michel U, Randler C. Outdoor light at night (LAN) is correlated with eveningness in adolescents. Chronobiol Int. 2012;29:502-8.

159. Hurley S, Nelson DO, Garcia E, Gunier R, Hertz A, Reynolds P. A cross-sectional analysis of light at night, neighborhood sociodemographics and urinary 6-sulfatoxymelatonin concentrations: implications for the conduct of health studies. Int J Health Geogr. 2013;12:39.

160. Obayashi K, Saeki K, Iwamoto J, Ikada Y, Kurumatani N. Exposure to light at night and risk of depression in the elderly. J Affect Disord. 2013;151:331-6.

161. Bottino CJ, Rifas-Shiman SL, Kleinman KP, Oken E, Redline S, Gold D, et al. The association of urbanicity with infant sleep duration. Health Place. 2012;18:1000-5.

162. Borniger JC, McHenry ZD, Abi Salloum BA, Nelson RJ. Exposure to dim light at night during early development increases adult anxiety-like responses. Physiol Behav. 2014;133:99-106

163. Guadagni V, Burles F, Ferrara M, laria. The effects of sleep deprivation on emotional empathy. J Sleep Res 2014. In press.

164. Kyba CC, Ruhtz T, Fischer J, Hölker F. Cloud coverage acts as an amplifier for ecological light pollution in urban ecosystems. PLoS One. 2011;6:e17307.

165. Gaston KJ, Duffy JP, Gaston S, Bennie J, Davies TW. Human alteration of natural light cycles: causes and ecological consequences. Oecologia 2014. In press.

166. Sagioglou NE, Manta AK, Giannarakis IK, Skouroliakou AS, Margaritis LH. Apoptotic cell death during Drosophila oogenesis is differentially increased by electromagnetic radiation depending on modulation, intensity and duration of exposure. Electromagn Biol Med. 2014;21:1-14.

167. Razavinasab M, Moazzami K, Shabani M. Maternal mobile phone exposure alters intrinsic electrophysiological properties of CA1 pyramidal neurons in rat offspring. Toxicol Ind Health 2014. In press.

168. Lewczuk B, Redlarski G, Zak A, Ziółkowska N, Przybylska-Gornowicz B, Krawczuk M. Influence of electric, magnetic, and electromagnetic fields on the circadian system: current stage of knowledge. Biomed Res Int. 2014;2014:169459.

169. Liu H, Chen G, Pan Y, Chen Z, Jin W, Sun C, et al. Occupational electromagnetic field exposures associated with sleep quality: a cross-sectional study. PLoS One. 2014:9:e110825.

170. Dubos R. Man adapting. New Haven: Yale University Press; 1965. p. 51.

171. Dubos R. The mirage of health: utopias, progress and biological change. New Brunswick, NJ: Rutgers University Press; 1959. p. 113.

172. Speldewinde $P C$, Cook A, Davies $P$, Weinstein $P$. A relationship between environmental degradation and mental health in rural Western Australia. Health Place. 2009;15:865-72.

173. Donovan GH, Butry DT, Michael YL, Prestemon JP, Liebhold AM, Gatziolis D, et al. The relationship between trees and human health: evidence from the spread of the emerald ash borer. Am J Prev Med. 2013:44:139-45.

174. Willox AC, Harper SL, Edge VL, Landman K, Houle K, Blake S, et al. Climate change and mental health: an exploratory case study from Rigolet, Nunatsiavut, Canada. Climate Change. 2013;121:255-70.

175. Willox AC, Harper SL, Ford JD, Edge VL, Landman K, Houle K, et al. The land enriches the soul: on climatic and environmental change, affect, and emotional health and well-being in Rigolet, Nunatsiavut, Canada. Emotion Space Soc. 2013;6:14-24. 
176. Semenza JC. Climate change and human health. Int J Environ Res Publ Health. 2014;11:7347-53.

177. Hendrryx M. Innes-Wimsatt. Increased risk of depression for people living in coal mining areas of central Appalachia. Ecopsychol. 2013;5:179-87.

178. Jiang B, Li D, Larsen L, Sullivan WC. A dose-response curve describing the relationship between urban tree cover density and self-reported stress recovery. Environ Behav 2014. In press.

179. Dubos R. Man and his environment: scope, impact and nature. In: Marquis RW, editor. Environmental Improvement. Washington DC: United States Department of Agriculture, Graduate School Press; 1966. p. 3-21.

180. Berman MG, Jonides J, Kaplan S. The cognitive benefits of interacting with nature. Psychol Sci. 2008;19:1207-12.

181. Shin WS, Shin CS, Yeoun PS, Kim JJ. The influence of interaction with forest on cognitive function. Scand J Forest Res. 2011;26:595-8.

182. Faber-Taylor A, Kuo FE. Children with attention deficits concentrate better after walk in the park. J Atten Disord. 2009;12:402-9.

183. Berman MG, Kross E, Krpan KM, Askren MK, Burson A, Deldin PJ, et al. Interacting with nature improves cognition and affect for individuals with depression. J Affect Disord. 2012;140:300-5.

184. Atchley RA, Strayer DL, Atchley P. Creativity in the wild: improving creative reasoning through immersion in natural settings. PLoS One. 2012;7:e51474.

185. Ryan R, Weinstein N, Bernstein J, Brown KW, Mistretta L, Gagne M. Vitalizing effects of being outdoors and in nature. J Environ Psychol. 2010;30:159-68.

186. Park BJ, Tsunetsugu Y, Kasetani T, Kagawa T, Miyazaki Y. The physiological effects of Shinrin-yoku (taking in the forest atmosphere or forest bathing): evidence from field experiments in 24 forests across Japan. Environ Health Prev Med. 2010;15:18-26

187. Tsunetsugu Y, Park BJ, Miyazaki Y. Trends in research related to "Shinrin-yoku" (taking in the forest atmosphere or forest bathing) in Japan. Environ Health Prev Med. 2010;15:27-37.

188. Takayama N, Korpela K, Lee J, Morikawa T, Tsunetsugu Y, Park BJ, et al. Emotional, restorative and vitalizing effects of forest and urban environments at four sites in Japan. Int J Environ Res Publ Health. 2014;11:7207-30

189. Song C, Ikei H, Igarashi M, Miwa M, Takagaki M, Miyazaki Y. Physiological and psychological responses of young males during spring-time walks in urban parks. J Physiol Anthropol. 2014;33:8.

190. Toda M, Den R, Hasegawa-Ohira M, Morimoto K. Effects of woodland walking on salivary stress markers cortisol and chromogranin A. Complement Ther Med. 2013;21:29-34.

191. Mao GX, Cao YB, Lan XG, He ZH, Chen ZM, Wang YZ, et al. Therapeutic effect of forest bathing on human hypertension in the elderly. J Cardiol. 2012;60:495-502.

192. Mao GX, Lan XG, Cao YB, Chen ZM, He ZH, Lv YD, et al. Effects of short-term forest bathing on human health in a broad-leaved evergreen forest in Zhejiang Province. China Biomed Environ Sci. 2012;25:317-24.

193. Horiuchi M, Endo J, Akatsuka S, Uno T, Hasegawa T, Seko Y. Influence of forest walking on blood pressure, profile of mood states, and stress markers from the viewpoint of aging. J Aging Gerontol. 2013;1:9-17.

194. Sung J, Woo JM, Kim W, Lim SK, Chung EJ. The effect of cognitive behavior therapy-based "forest therapy" program on blood pressure, salivary cortisol level, and quality of life in elderly hypertensive patients. Clin Exp Hypertens. 2012;34:1-7

195. Song C, Joung D, Ikei H, Igarashi M, Aga M, Park BJ, et al. Physiological and psychological effects of walking on young males in urban parks in winter. J Physiol Anthropol. 2013;32:18.

196. Song C, Ikei H, Lee J, Park BJ, Kagawa T, Miyazaki Y. Individual differences in the physiological effects of forest therapy based on Type A and Type B behavior patterns. J Physiol Anthropol. 2013;32:14.

197. Chang CY, Lin YH, Chou MT. Experiences and stress reduction of viewing natural environmental settings. Acta Hortic. 2008;775:139-46.

198. Chang CY, Hammitt WE, Chen PK, Machnik L, Su WC. Psychophysiological responses and restorative values of natural environments in Taiwan. Landscape Urban Plan. 2008;85:79-84.

199. Ulrich RS. Natural versus urban scenes: some psychophysiological effects Envriron Behav. 1981;13:523-56.

200. Aspinall $P$, Mavros P, Coyne R, Roe J The urban brain: analysing outdoor physical activity with mobile EEG. Br J Sports Med 2014. In press.

201. Tsunetsugu Y, Miyazaki Y. Measurement of absolute hemoglobin concentrations of prefrontal region by near-infrared time-resolved spectroscopy: examples of experiments and prospects. J Physiol Anthropol Appl Human Sci. 2005;24:469-72.
202. Igarashi M, Yamamoto T, Lee J, Song C, Ikei H, Miyazaki Y. Effects of stimulation by three-dimensional natural images on prefrontal cortex and autonomic nerve activity: a comparison with stimulation using twodimensional images. Cogn Process 2014. In press.

203. Igarashi M, Song C, Ikei H, Miyazaki Y. Effect of stimulation by foliage plant display images on prefrontal cortex activity: a comparison with stimulation using actual foliage plants. J Neuroimaging 2014. In press.

204. Kim TH, Jeong GW, Baek HS, Kim GW, Sundaram T, Kang HK, et al. Human brain activation in response to visual stimulation and rural urban scenery pictures: a functional magnetic resonance imaging study. Sci Total Environ. 2010;408:2600-7.

205. Kim GW, Song JK, Jeong GW. Neuro-anatomical evaluation of human suitability for rural and urban environment by using fMRI. Korean J Med Phys. 2011;22:18-27.

206. Kim GW, Jeong GW, Kim TH, Baek HS, Oh SK, Kang HK, et al. Functional neuroanatomy associated with natural and urban scenic views in the human brain: 3.0 T functional MR imaging. Korean J Radiol. 2010;11:507-13.

207. Kim GW, Jeong GW. Brain activation patterns associated with the human comfortability of residential environments: 3.0-T functional MRI. Neuroreport. 2014;25:915-20.

208. Lederbogen F, Kirsch P, Haddad L, Streit F, Tost H, Schuch P, et al. City living and urban upbringing affect neural social stress processing in humans. Nature. 2011;474:498-501.

209. Pati D, O'Boyle M, Amor C, Hou J, Valipoor S, Fang D. Neural correlates of nature stimuli: an FMRI study. HERD. 2014;7:9-28.

210. Kim TH, Song JK, Jeong GW. Neural responses to the human color preference for assessment of eco-friendliness: a functional magnetic resonance imaging study. Int J Environ Res. 2012;6:953-60.

211. Ulrich RS, Simons RF, Losito BD, Fiorito E, Miles MA, Zelson M. Stress recovery during exposure to natural and urban environments. J Environ Psychol. 1991:11:201-30.

212. Gladwell VF, Brown DK, Barton JL, Tarvainen MP, Kuoppa P, Pretty J, et al. The effects of views of nature on autonomic control. Eur J Appl Physiol. 2012;12:3379-86

213. Lee MS, Park BJ, Lee J, Park KT, Ku JH, Lee JW, et al. Physiological relaxation induced by horticultural activity: transplanting work using flowering plants. J Physiol Anthropol. 2013;32:15.

214. Yamane K, Kawashima M, Fujishige N, Yoshida M. Effects of interior horticultural activities with potted plants on human physiological and emotional status. Acta Horticult. 2004;639:37-43.

215. Song C, Ikei H, Igarashi M, Miwa M, Takagaki M, Miyazaki Y. Physiological and psychological responses of young males during spring-time walks in urban parks. Physiol Anthropol. 2014;33:8.

216. Brown DK, Barton JL, Gladwell VF. Viewing nature scenes positively affects recovery of autonomic function following acute-mental stress. Environ Sci Technol. 2013:47:5562-9.

217. Alvarsson JJ, Wiens S, Nilsson ME. Stress recovery during exposure to nature sound and environmental noise. Int J Environ Res Public Health 2010, 7:1036-46. Am J Physiol Regul Integr Comp Physiol. 2006;291:R822-7.

218. Goel N. An arousing, musically enhanced bird song stimulus mediates circadian rhythm phase advances in dim light. Am J Physiol Regul Integr Comp Physiol. 2006:291:R822-7.

219. Oka T, Hayashida S, Kaneda Y, Takenaga M, Tamagawa Y, Tsuji S, et al. Green odor attenuates a cold pressor test-induced cardiovascular response in healthy adults. Biopsychosoc Med. 2008;2:2.

220. Hyun-Ju J, Eijiro F, Tae-Dong C. An experimental study on physiological and psychological effects of pine scent. J Kor Inst Landscape Architect. 2010:38:1-10.

221. Koga K, Iwasaki Y. Psychological and physiological effect in humans of touching plant foliage - using the semantic differential method and cerebral activity as indicators. J Physiol Anthropol. 2013;32:7.

222. Benfield JA, Taff BD, Newman P, Smyth J. Natural sound facilitates mood recovery. Ecopsychol. 2014;6:183-8.

223. Markevych I, Tiesler C, Fuertes E, Romanos M, Dadvand P, Nieuwenhuijsen $M J$, et al. Access to urban green spaces and behavioral problems in children: results from the GINIplus and LISAplus studies. Environ Int. 2014;71:29-35.

224. Fiouri $E_{\text {, Midouhas }}$, Joshi $H$. The role of urban neighbourhood green space in children's emotional and behavioral resilience. J Environ Psychol. 2014:40:179-86 
225. Kuo FE, Taylor AF. A potential natural treatment for attention-deficit/ hyperactivity disorder: evidence from a national study. Am J Publ Health. 2004:94:1580-6.

226. Faber-Taylor A, Kuo FE, Sullivan WC. Coping with ADD: the surprising connection to green play settings. Environ Behav. 2001;33:54-77.

227. Amoly E, Dadvand P, Forns J, López-Vicente M, Basagaña X, Julvez J, et al. Green and blue spaces and behavioral development in Barcelona schoolchildren: the BREATHE Project. Environ Health Perspect 2014. In press.

228. Berto R. The role of nature in coping with psycho-physiological stress: a literature review of restorativeness. Behav Sci. 2014:4:394-409.

229. Sandry J, Schwark J, Hunt G, Geels K, Rice S. Superior visual search accuracy after exposure to natural relative to urban environments. Proc Hum Factors Ergon Soc Annu Meet. 2012;56:1624-8.

230. Berto R. Exposure to restorative environments helps restore attentional capacity. J Environ Psychol. 2005;25:249-59.

231. Berto R, Baroni MR, Zainaghi A, Bettella S. An exploratory study of the effect of high and low fascination environments on attention fatigue. J Environ Psychol. 2010;30:494-500

232. Joye $Y$, Pals R, Steg L, Evans BL. New methods for assessing the fascinating nature of nature experiences. PLoS One. 2013;8:e65332.

233. Gamble KR, Howard Jr JH, Howard DV. Not just scenery: viewing nature pictures improves executive attention in older adults. Exp Aging Res. 2014:40:513-30

234. Chow JT, Lau S. Nature gives us strength: exposure to nature counteracts ego-depletion. J Soc Psychol 2014. In press.

235. Matsuoka R. Student performance and high school landscapes: examining the links. Landsc Urban Plan. 2010:97:273-82.

236. Wu CD, McNeely E, Cedeno-Laurent JG, Pan WC, Adamkiewicz G, Dominici $F$, et al. Linking student performance in Massachusetts elementary schools with the "greenness" of school surroundings using remote sensing. PLoS One. 2014;9:e108548.

237. Benfield JA, Rainbolt GA, Bell PA, Donovan G. Classrooms with nature views: evidence of differing student perceptions and behaviors. Environ Behav 2014. In press.

238. Lottrup L, Stigsdotter UK, Henrik Meilby H, Anne Grete Claudi AG. The workplace window view: a determinant of office workers' work ability and job satisfaction. Landscape Res 2014. In press.

239. Nieuwenhuis M, Knight C, Postmes T, Haslam SA. The relative benefits of green versus lean office space: three field experiments. J Exp Psychol Appl 2014. In press.

240. Nieuwenhuis M, Knight C, Postmes T, Haslam SA. The relative benefits of green versus lean office space: three field experiments. J Exp Psychol Appl. 2014;20:199-214

241. Pulcu E, Trotter PD, Thomas EJ, McFarquhar M, Juhasz G, Sahakian BJ, et al. Temporal discounting in major depressive disorder. Psychol Med. 2013;1:1-10

242. Lu Q, Tao F, Hou F, Zhang Z, Sun Y, Xu Y, et al. Cortisol reactivity, delay discounting and percent body fat in Chinese urban young adolescents. Appetite. 2014;72:13-20.

243. Irvine MA, Worbe Y, Bolton S, Harrison NA, Bullmore ET, Voon V. Impaired decisional impulsivity in pathological videogamers. PLoS One. 2013:8: e75914.

244. van der Wal AJ, Schade HM, Krabbendam L, van Vugt M. Do natural landscapes reduce future discounting in humans? Proc Biol Sci. 2013;280:20132295

245. Berry MS, Sweeney MM, Morath J, Odum AL, Jordan KE. The nature of impulsivity: visual exposure to natural environments decreases impulsive decision-making in a delay discounting task. PLoS One. 2014;9:e97915.

246. Weinstein N, Przybylski AK, Ryan RM. Can nature make us more caring? Effects of immersion in nature on intrinsic aspirations and generosity. Pers Soc Psychol Bull. 2009:35:1315-29.

247. Gueguen N, Stefan J. "Green altruism": short immersion in natural green environments and helping behavior. Environ Behav 2014. In press.

248. Shiota MN, Keltner D, Mossman A. The nature of awe: elicitors, appraisals, and effects on self-concept. Cogn Emotion. 2007;21:944-63.

249. Rudd M, Vohs KD, Aaker J. Awe expands people's perception of time, alters decision making, and enhances well-being. Psychol Sci. 2012;23:1130-6.

250. Zelenski JM, Nisbet E. Happiness and feeling connected: the distinct role of nature relatedness. Environ Behav. 2014;46:3-23.

251. Nisbet EK, Zelenski JM. Underestimating nearby nature: affective forecasting errors obscure the happy path to sustainability. PsycholSci. 2011;22:1101-6.
252. Cervinka R, Roderer K, Hefler E. Are nature lovers happy? On various indicators of well-being and connectedness to nature. J Health Psychol. 2012;17:379-88.

253. Nisbet EK, Zelenski JM, Murphy SA. Happiness is in our nature: exploring nature relatedness as a contributor to subjective well-being. J Happin Stud. 2011;12:303-22

254. Nisbet EK, Zelenski JM. The NR-6: a new brief measure of nature relatedness. Front Psychol. 2013;4:813.

255. Martyn P, Brymer E. The relationship between nature relatedness and anxiety. J Health Psychol 2014. In press.

256. Ginting H, Näring G, Kwakkenbos L, Becker ES. Spirituality and negative emotions in individuals with coronary heart disease. Cardiovasc Nurs. 2014 In press.

257. Zhang JW, Piffa PK, lyerb R, Spassena K, Keltner D. An occasion for unselfing: beautiful nature leads to prosociality. J Environ Psychol. 2014;37:61-72.

258. Zhang JW, Howell RT, lyerb R. Engagement with natural beauty moderates the positive relation between connectedness with nature and psychological well-being. J Environ Psychol. 2014;38:55-63.

259. Howell AJ, Passmore HA, Buro K. Meaning in nature: meaning in life as a mediator of the relationship between nature connectedness and wellbeing. J Happin Stud. 2013:14:1681-96.

260. Howell AJ, Dopko RL, Passmore HA, Buro K. Nature connectedness: associations with well-being and mindfulness. Pers Indiv Diff. 2011;51:166-71.

261. Lin YH, Tsai CC, Sullivan WC, Chang PJ, Chang CY. Does awareness effect the restorative function and perception of street trees? Front Psychol. 2014;5:906.

262. Metz A. Back to nature: the impact of nature relatedness on empathy and narcissism in the millennial generation. Thesis. James Madison University, Department of Psychology; 2014. http://www.worldcat.org/title/back-tonature-the-impact-of-nature-relatedness-on-empathy-and-narcissism-in-themillennial-generation/oclc/885415006

263. Shwartz A, Cosquer A, Jaillon A, Piron A, Julliard R, Raymond R, et al. Urban biodiversity, city-dwellers and conservation: how does an outdoor activity day affect the human-nature relationship? PLoS One. 2012;7:e38642.

264. Passmore HA, Howell AJ. Nature involvement increases hedonic and eudemonic well-being: a two-week experimental study. Ecopsychol. 2014;6:148-54

265. Collado S, Corraliza JA. Children's restorative experiences and self-reported environmental behaviors. Environ Behav 2014. In Press.

266. Dubos R. Man, medicine and environment. New York, NY: New American Library Inc; 1969

267. Sushinsky JR, Rhodes JR, Possingham HP, Gill TK, Fuller RA. How should we grow cities to minimize their biodiversity impacts? Glob Chang Biol. 2013;19:401-10.

268. Romanelli C, Corvalan C, Cooper HD, Manga L, Maiero M, CampbellLendrum D. From Manaus to Maputo: toward a public health and biodiversity framework. Ecohealth. 2014;11:292-9.

269. Sen T, Samanta SK. Medicinal plants, human health and biodiversity: a broad review. Adv Biochem Eng Biotechnol 2014. In press.

270. Cardinale BJ, Duffy JE, Gonzalez A, Hooper DU, Perrings C, Venail P, et al. Biodiversity loss and its impact on humanity. Nature. 2012:486:59-67.

271. Fuller RA, Irvine KN, Devine-Wright P, Warren PH, Gaston KJ. Psychological benefits of greenspace increase with biodiversity. Biol Lett. 2007:3:390-4.

272. Luck GW, Davidson P, Boxall D, Smallbone L. Relations between urban bird and plant communities and human well-being and connection to nature. Conservat Biol. 2011;25:816-26.

273. Schwartz A, Turbe A, Simon L, Julliard R. Enhancing urban biodiversity and its influence on city-dwellers: an experiment. Biol Conservat. 2014;171:82-90.

274. Hedblom M, Heyman E, Antonsson H, Gunnarsson B. Bird song diversity influences young people's appreciation of urban landscapes. Urban Forest Urban Green 2014. In press

275. Kemperman A, Timmermans H. Green spaces in the direct living environment and social contacts of the aging population. Land Urban Plan 2014;129:44-54.

276. Dadvand P, Villanueva CM, Font-Ribera L, Martinez D, Basagaña X, Belmonte J, et al. Risks and Benefits of green spaces for children: a cross-sectional study of associations with sedentary behavior, obesity, asthma, and allergy. Environ Health Perspect 2014. In press.

277. Tuke DH. A dictionary of psychological medicine, vol. I. London: JA Churchill; 1892.

278. Biophilism. The marion star. 1895. p. 6 
279. Adams CJ. Biophilism. Forest Stream. 1896;47:278.

280. Biophilism. Dog Fancier. 1907, 16:4.

281. Adams CJ. Biophilism. Phrenol J Sci Health. 1907;120:14-6.

282. McGrath M. Fromm, ethics, and education. Bull Bureau Sch Serv. 1969;42:5-31.

283. Smith AW. Telics. Nat Parks Conserv. 1973:47:2, 35.

284. Wilson EO. The column—biophilia. New York Times Sunday Magazine; 1979. p 43.

Submit your next manuscript to BioMed Central and take full advantage of:

- Convenient online submission

- Thorough peer review

- No space constraints or color figure charges

- Immediate publication on acceptance

- Inclusion in PubMed, CAS, Scopus and Google Scholar

- Research which is freely available for redistribution 